\title{
HUMAN RIGHTS OF HIJRAS IN BANGLADESH: AN ANALYSIS
}

\author{
Arobia Khanam*
}

\begin{abstract}
Ensuring human rights for Hijra is one of the prerequisites of a just society. The Hijras are perceived to live at risk of being the victims of social harassment everywhere due to negative societal attitudes towards this section. For this reason, they are far behind from the enjoyment of basic needs and fundamental rights that impede the realization of the human rights of Hijras. This article explores the reasons for the marginalization of the Hijra community and sheds light on how to ensure human rights in the prevailing legal structure of Bangladesh by overcoming the challenges. Consequently, this paper attempts to identify the effectiveness of the existing laws and policies to address the problem faced by hijras and thus find out the gaps. The author shows that leaving them far away from the mainstream society due to lack of implementation of existing laws, policies and lack of cordial attitude of the family as well as because of lacking in knowledge of hijras regarding the laws and policies. Mixed methods and snowball techniques have been applied to this study to collect and analyze the data. To this end, the author has stipulated some recommendations to sort out the problems and challenges.
\end{abstract}

Keywords: Hijra Community, Human Rights, Social Attitudes, Marginalization, Inclusion.

\section{Introduction}

In the contemporary world, society looks down upon the gender variant people known as Hijras because of being distinct which keep them in a vulnerable position in the society (Khan, 2009). Tove Stenqvist argued that the Hijra community is considered as one of the most neglected groups in Bangladesh (Stenqvist, 2015). Society always disapproves of their unnatural approach and ultimately deprecates them which resulted in receiving diverse treatments concerning basic needs in comparison to other kinfolks who are in the twofold

\footnotetext{
* Arobia Khanam is an Assistant Judge, Narsingdi Judge Court, Ministry of Law, Justice and Parliamentary Affairs, Government of the People's Republic of Bangladesh. Email: arobialaw@gmail.com
}

Social Science Review [The Dhaka University Studies, Part-D], Vol. 38, No. 1, June 2021 DOI: https://doi.org/10.3329/ssr.v38i1.56533 
civic norm (Khan, 2009). Moreover, the feminine approach of adolescent Hijras is responsible to be victimized by sexual assault (Hossain, 2012). Furthermore, the stigma of being Hijra in Bangladesh starts within the family constellation to safeguard their kindred from further community dishonour (Nanda, 1999). In addition to their social discriminations; members of the Hijra community do face discrimination regularly as other Bangladeshi citizens do not accept their existence (Khan, 2009). They are being marginalized and excluded from mainstream society due to the complex gender approach. Hijra communities are frequently faced with physical torture while begging in different places of Bangladesh and are targeted for extortion by police as well as the crime which is committed toward the hijra community is neglected by the state. Though the variation in gender is not self-made whereas discriminatory attitude by the society is the violation of inalienable rights. However, the Government of the People's Republic of Bangladesh has adopted an attempt to develop the livelihood of the Hijra community. For instance, the Ministry of Social Welfare of the People's Republic of Bangladesh has enacted a policy in 2013 titled 'Implementation Manual of Livelihood development of Hijra 2013' which has recognized Hijras as 'transgender' and the policy emphases on the social development of hijras by providing education, training, and increasing dignity in their familial structure. Nevertheless, hijras are being deprived of enjoying human rights in the same way as other siblings due to lack of implementation/effectiveness, application of existing laws as well as the existing policies, lack of knowledge of hijras about the existing laws, policies, and cordial attitude as well as neglectful behaviour of family and society. The problems which are faced by the Hijra community are not less important in any sense because leaving behind one sector of the society or putting less emphasis upon the demands of this backward section no family, society, or country will make progress.

\section{Methodology of the Study}

The research is an outcome of the combined efforts of quantitative and qualitative approaches. The research has been conducted in the three purposively selected localities of Dhaka city - Chankhar Pool, Dhaka University Campus, and Hatirpool because these areas are more accessible and convenient to find out the respondents and taking interviews since the author has been living near the localities. Since there is no database of accurate information about the Hijras of Dhaka city, the snowball sampling technique has been applied here to collect 
primary data and information from the aforesaid localities while secondary data gathered from distinct books, periodicals, pertinent newspapers and websites, thesis or discourses, Constitution of the Peoples' Republic of Bangladesh and the Universal Declaration of Human Rights 1948, International Covenant on Civil and Political Rights 1966 and International Covenant on Economic, Social and Cultural rights 1966 and the United Nations Charter 1945. A total number of thirty respondents have been incorporated in this study. Hence, the semistructured questionnaire has been designed for taking interviews because of this type of interviewing offers resilience and privilege to both interviewers and interviewees regarding organizing the substance and questions of an interview (Gubrium and Holstein, 2001). The MS- Excel software has been used in this research to analyse the quantitative data collected through the survey method.

Demographic features of the participants

Table 1: Demographic attributes of the Participants; Researcher's dataset

\begin{tabular}{|c|c|c|c|}
\hline $\begin{array}{c}\text { Aspects of } \\
\text { Participants }\end{array}$ & Range/Type/level & Frequency & Percentage $(\%)$ \\
\hline \multirow{4}{*}{ Age } & $20-25$ & 3 & 10 \\
\hline & $25-30$ & 7 & 23.33 \\
\hline & $30-35$ & 14 & 46.67 \\
\hline & $35-40$ & 6 & 20 \\
\hline \multirow{5}{*}{ Education } & Literate/signature & 6 & 20 \\
\hline & Primary & 12 & 40 \\
\hline & Secondary & 11 & 36.67 \\
\hline & Higher Secondary & 0 & 0 \\
\hline & Tertiary & 1 & 3.33 \\
\hline \multirow{4}{*}{ District of Origin } & Manikganj & 11 & 36.67 \\
\hline & Bhairab & 7 & 23.33 \\
\hline & Kishoreganj & 6 & 20 \\
\hline & Sunamganj & 6 & 20 \\
\hline \multirow{2}{*}{ Religion } & Muslim & 26 & 86.67 \\
\hline & Hindu & 4 & 13.33 \\
\hline
\end{tabular}




\section{Ethical Consideration}

Before collecting data, the author took the consent of the interviewers on a written paper and ensured that if they give opinion on the questionnaires, then it will not be harmful to them. To maintain confidentiality, their address like villages, upazila, and parents' names have been kept secret whereas their names and names of the district have been disclosed with their free consent. The author has revealed some information in the methodology section with the consent of the participants as their demographic features. Even the researcher has not analysed any data that will be erratic for anybody or the organization. In essence, the researcher has followed complete research ethics towards this end.

\section{Objectives of the Study}

The objective of this article is to delve into problems and challenges faced by the Hijra community in terms of the enjoyment of human rights and the way forward. To this end, other objectives include a) To analyse the reasons for historical and socio-legal exclusion of Hijras; b) To outlines the effectiveness of the existing laws and policies to address the problems faced by the hijra community and thus to find out the gaps of the existing laws and policies; and c) to sort out the challenges and to stipulate some recommendations for their inclusion in the mainstream society.

\section{Theoretical Framework Definition of Hijra}

The precise meaning of Hijra (a similar word in English is "Hermaphrodite" which means a being that contains male and female sexual organs) is quite difficult to be expressed in English. Nevertheless, as stated by Nanda "the astounding English conveyance of the term Hijra, which is emerged from Urdu, could be portrayed as 'hermaphrodite' (inter-sex) which are connoted as infecundity that implies infertility to work in the male procreation role" (Nanda,1999). Following this 'hermaphrodite' denotes to an enervated macho whose private parts are inconclusively man at child bed and have been heretofore authorized to the male sex, would be re-classified as inter- sexed. The "Eunuch" is emanated from the Greek word Eunoukhos (Miller, 2004) which factually means mattress chamber warden (Nanda, 1999). It is in this sense that during the Mughal era they had been supervising harems (Chettiar, 2015). As eunuchs were 
erotically impotent, so they were considered as suitable guards for harems. However, Hijras' sexual identity generates complexity in the mainstream society while they exist in diverse social and gender roles. The Chakrapani (2010) observed that Hijras are organically man but repudiate their mannish existence with the flux of time to pinpoint as 'women' or not men'. As Hijras usually recognize themselves as not manlike and choose to have intercourse with men, thus, they are distinguished by society as homophile (Chakrapani, 2010). Hahm argued that Hijras are those who are birthing inter-sexed and can survive as both man and woman (Hahm, 2010). In contrast, Hijras could be male who have taken emasculation or wish to encounter enervation and lodge as lassie. Considering all these perceptions, this study defines Hijra as 'a person who is innate as male or equivocal vulva sex, frequently keep themselves in females 'contribution and draw attention as a lady but recognizes themselves either as heterosexual or aside from customary man-woman genic role, for example, Hijra, Kothi, third gender (Hahm, 2010).

\section{Human Rights}

Human Rights are neither emerged from the social order nor conferred upon the individual by the society. They reside intrinsically in the individual human beings independent of and even before his taking part in the society. As such, they are the output of acknowledgment by the nation, but they are judiciously independent of the legal system for their persistence. For this reason, many thinkers have determined the origin of human rights to the rules of right and wrong which are inherent in people and are not created by society or court judges (Pagels, 1979).

Human Rights are inalienable which cannot be taken away by anyone. These rights are intrinsic in the very nature of human beings. Jacques Maritain (2012) has said that the human being possesses rights because of the very fact that it is a person, a whole; a master of itself and its acts by natural law, the human person has the right to be respected, is the subject of rights, and possesses rights (Marian, 1951). It is a fact that human rights are emanated directly or indirectly from the very nature of man. From this, it may be argued that by being human, one inheres all those accredited which are ingrained in human personality, and natural rights being one among those ascribed are inherited naturally. This leads to inexorable findings that all human beings are equal which may be beneficial to quote Barnard Mayo (1967) also that Human Rights are the rights that a human 
being has in virtue of whatever features he has that is both particularly and invariably human (Mayo, 1967). As Bangladesh is a signatory and ratified the Universal Declaration of Human Rights, International Covenant on Civil and Political Rights, and International Covenant on Economic, Social as well as Cultural Rights, so it is the bounden duty to maintain these.

\section{Historical Discrimination and Exclusion of Hijras International Context}

During the period of Mughal, eunuchs or Khawaja Sira, as they were called, were the most faithful authoritative domestic workers. They displayed enormous ability, esteem and some managed to accumulate a huge amount of wealth. They were generally appointed as wardens of the harem, and some rose to the ranks of army generals, illustrious teachers, and court consultants. With the downturn of the Mughal Empire and the emergence of British rule, their influence was declined (Gul, 2018). At the beginning of the British era in the Indian subcontinent Hijras used to receive shielding and interests by some Indian states by entering the Hijra community. Generally, the benefits encompass the delivery of land, rights of food, and a lesser amount of money from farmland houses in a certain area which were in due course of time taken away by the British because the land was not succeeded by consanguineous or family (Reddy, 2005). In 1871, the colonial power introduced the Criminal Tribes Act (CTC) which required registration and dominance of eunuchs. There was a blanket inkling of kidnapping, castration, and sodomy.

Under the CTC, putting on womanish clothing was a penalizing offense for males which envisages that "any eunuch who appears, embellished or adorned like a female, in a public place, or any other place, intending to be seen from a public area, or who sways or plays chords or sound, or participates in any public demonstration" could be sentenced to up to two years of imprisonment including a fine. Moreover, the CTC criminalized "all persons of the man who acknowledge themselves or by medical report seem to be powerless". The Colonial law impoverished hijras from their main source of earnings and any type of equitable rights. It plunged them further into destitution and communal exclusion. The annalists announced that the British wanted to strike out the Hijras as a discernible socio-cultural classification and genetic recognition. While they did not triumph in doing so, many trustworthy figureheads embraced the colonial power's 
realization. Nowadays, traditionalist Mullahs resists reforms that defence Hijra rights which expedited the ending of colonial legacy at a slow pace (Gul, 2018).

\section{National Context}

Deprivation in terms of Socio-Legal Human Rights in Bangladesh: Following the British era, the Hijra community has been receiving their livelihoods by blessings of children and performing the dance at weddings. Hijras have been standing at the margin of the prevailing societal activities as they are not honoured anymore by the ordinary social norms. However, as of now, Hijras usually do not prefer to dance on different occasions in society but often carry out if they are paid with respect. When Bangladesh was the segment of West Pakistan, the state used to impart allowances for Hijras during old ages. This allowance was kept up after the independence of Bangladesh but subsequently, they have been impoverished by this allotment (Hossain, 2012). Additionally, the culture of Hijras and gendered recognition has been opposed and they are termed as impaired both sexually and mentally by scholars and doctors (Hossain, 2012). As Hijras have been recognized in Bangladesh as transgender, so they will enjoy the same rights as other sexes. In Bangladesh, the Ministry of Social Welfare of the People's Republic of Bangladesh has enacted a policy in 2013 titled 'Implementation Manual of Livelihood development of Hijra 2013' which recognized Hijras as transgender where the objectives and purposes of the policy emphases on the social development of hijras by providing education, training and increasing dignity in their familial structure but did not particularize their health facilities and how their familial status will be increased, whether they will live with their family or not and how they will remain in their family or whether they will get their respective shares according to the law of inheritance, etc., as well as no rules or guidelines are framed till now in Bangladesh. The problem is legally suppressed by some related constitutional provisions and the Universal Declaration of Human Rights, International Covenant on Civil, Political Rights as well as International Covenant on Economic, Social and Cultural Rights, though the term "transgender" has not been incorporated separately in the various provisions of the constitution of the Peoples' Republic of Bangladesh, the Universal Declaration of Human Rights, International Covenant on Civil, Political Rights as well as International Covenant on Economic, Social and Cultural Rights but as a transgender they will have the same rights as enjoyed by others gender and though the term "transgender" is not guaranteed by the 
Constitution of the Peoples' Republic of Bangladesh because the rights enshrined in the constitution apply to all citizens. Now, these are going to be discussed consecutively given the provisions of the constitution, the Universal Declaration of Human Rights, International Covenant on Civil and Political Rights as well as International Covenant on Economic, Social and Cultural Rights and based on the social practice. In this connection inequality can be termed as one sort of exploitation whereas preamble of the Constitution of the People's Republic of Bangladesh pledges that it shall be the fundamental aim of the state to realize a socialist society, free from exploitation a society in which the rule of law, fundamental human rights, freedom, equality and justice, political, economic and social equality will be secured for all citizens (Constitution Preamble). So, from the very beginning, it has been ensured by the constitution where no discrimination in terms of social, political, and economic as well as cultural activities is allowed. Every citizen has the absolute right to enjoy all facilities granted and affirmed by the state. Accordingly, it is stated in the Constitution that the Republic shall be a democracy in which fundamental human rights and freedoms and respect for the dignity and worth of the human person will be guaranteed (Constitution, Article, 11). Hijras should be neither laborious nor treated as a citizenry that is unable to achieve goals such as liberty, self-determination, and nobility, but as human beings with distinctive, limitless prospective. The old anti standpoint underscores infirmity, contemplates immobilized persons as gadgets of cooperation, and provides equipment to make impairments. This includes flaws to furnish the positive actions they require to have an approach to conventional services and resources making certain rapid, long-standing, fruitful education, professional tutoring, endowment, and fitness programs (Oksala, 2005).

\section{Present Status of Hijra Community in Bangladesh}

In Bangladesh, Hijra is now officially recognized as a transgender next to the traditional man and woman. The social life and annals of the Hijra community implied how their status changed gradually which dominants their common roles as well. As Hijras in Bangladesh are a separate gender now, they will get equal rights in the various sectors of the society such as food, clothing, education, health, and housing as well as in the job sectors and will be prioritized because of being marginalized and backward section of the society but in practice, despite prevalent laws and policies, they are being deprived in terms of enjoyment of their human rights. The Ministry of Social Welfare is overseeing several 
community-based networks or programs through various underprivileged groups including Hijras to receive buttress for their sustenance.

\section{Belongingness to the family}

To be grown up within the family is the primary requirements of the individual for his/her existence or for surviving himself/herself. For this reason, it is the responsibility of the state to attain steady improvement in the material and cultural standard of living of the people, intending to secure food, clothing, housing to its citizens (Constitution, Article, 15); This very binary proposition is now enormously rooted in the communal academy starting from the brood and is used in every other clan of the society (West \& Zimmerman, 1987). But their sufferings do not stop here; they have to lead their lives by begging in the undesirable street. The Universal Declaration of Human Rights 1948, envisages that all human beings are born free and equal in dignity and rights. They are endowed with reason and conscience and should act towards one another in a spirit of brotherhood (UDHR, 1948 article 1). But the overriding standard present in Bangladeshi society have more or less forced Hijras to leave their families, as favouritism and misuse are usual factors in pubescent Hijra's life. The most pitiful fact is that they do not even have the choice to live with their families. The parents, siblings, and other relatives want to keep secret their identification. Consequently, they have to hide the fact about their sex or give up families which are no doubt, very rigid options to go for (Jebin \& Farhana, 2015). In some instances, Hijras are frequently regarded as generating societal complications which are harmful to the reputation of the family (Khan, 2009).They have equal rights as the other sex because no distinction can be made based on sex (UDHR, 1948, Article 2).The International Covenant on Economic, Social and Cultural Rights states that everyone has the right to an adequate standard of living for health and well-being him as well as family, including food, clothing, and housing and medical care, and necessary social services, (ICESCR 1966, Article,11) but their rights have not been guaranteed and protected yet by the society and family.

\section{Educational Facilities}

The educational right is a key to permit hijras to develop their potential soon and be incorporated into society. States must give aplomb a fruitful method of their right to education in conventional schools, and/or in special schools only if 
counting in ordinary schools is not plausible and if parents give consensus opinion on this matter. This also implies that aside from pedagogical skills, the education of hijra people must encompass a foundation for a self-sustaining life, malleable postures, and communal expertise. Adult education should furnish the highest gamut of facilities and comprise not only exceptional education or taking part in conventional grown-up educational programs but also teaching in primary expertise, self-directed, living skills, at all ages. Luncheon discrepancy, a free educational system to ensure fundamental rights initiatives to launch conventional, unconventional, and vocational educations and introduce a quota system to enlist hijra in academic institutes as well as for pursuing higher degrees in all universities (Mckeown, 1988). According to the Universal Declaration of Human Rights 1948, everyone has the right to education for human development, such as personality, promoting apprehension, forbearance, and heartiness amidst all states (UDHR, 1948, Article, 26). Consequently, they are not enjoying their full-fledged rights endowed onto them by international instruments. The Constitution of the People's Republic of Bangladesh envisages that it shall be the primary responsibility of the state to emancipate the backward section from all forms of exploitation (Constitution, Article, 14). Besides, the state shall adopt effective measures to establish a uniform, mass-oriented and universal system of education and extend free and compulsory education to all children to such stage as may be determined by law (Constitution, Article, 17). It is the mandate of the state to educate each person, whereas the state has failed to educate each hijra as enshrined in the constitution of the Peoples' Republic of Bangladesh. Furthermore, following the purpose and objectives of the policy 2013, during the year of 2012-2013; the Ministry of Social Welfare framed policy for educational development of hijra community and has specified in the section 9 subsection 1.5 that hijra will be identified through the survey by the directorate office of the Social Welfare and they will be gradually included on scholarship which will be provided among the Hijra students to appear for various levels of study (primary level-300/-, secondary level-500/- college level- 600/-, graduation and postgraduation level 1000/-) (Bandhu Social Welfare Society [BSWS], 2015). Moreover, Bangladesh has opened the first religious school named Dawatul Koran Third Sex Madrasah for transgender people at Kamrangirchar in Dhaka for hijra community irrespective of all ages and where more than 150 students will study Islamic and vocational subjects free of charge at privately funded (Chowdhury, 2020). 


\section{Employment Opportunities}

It is stated in the Constitution of the People's Republic of Bangladesh that the state shall strive to guarantee equality of opportunity to all citizenries. For this reason, the state shall endorse efficacious means to pull out communal and economic inequality and to make sure even-handed dispensing of wealth amidst citizens and of facilities to attain an unvaried level of economic development all over the Republic (Constitution, Article, 19). Moreover, according to the constitution, all natives are equal in the eye of law and are entitled to equal protection of the law and no one shall be discriminated against by the state on the ground of gender (Constitution, Articles, 27 28). At the same time, it is stated in the Constitution of Bangladesh that all citizens shall enjoy equal opportunity in terms of employment of office in the Republic and nothing in this article shall debar the state from creating any outstanding provision in favour of any underprivileged sector of the citizenry so that affixes their ample delineation in the service of the Republic (Constitution, Article, 29). To realize a socialist society free from exploitation, the state does not prohibit doing a favour for the backward and disadvantaged segments of the society (Sarker, 2007). In contrast, all Hijras faced discrimination in accessing conventional jobs (Halm, 2010). However, the Universal Declaration of Human Rights 1948 states that every human personality has the right to work, employment opportunities as per own choice, to the fair and convenient ambiance of work (UDHR, 1948, Article, 23). Although most of the respondents have the income-earning capability, results have identified that 45 percent of them are not satisfied with their current profession even if some of them are earning more from their current profession than their desired profession. For example, 64 percent of the respondents prefer government services where the basic pay is not very high but is dignified and such jobs are highly secured in the context of Bangladesh. However, they could not apply for those jobs due to their low educational attainment. All of them have identified the need for reservation of posts in the government services for the transgender people so that they can have a minimum possibility of availing those despite having a low qualification in comparison to others (positive discrimination (Jebin, 2018). It is mentionable that government furnished them with the opportunity of training on diverse trades, as haircutting, beautification, driving, farming, handicrafts, computer, mobile phone, television, refrigerator, air-condition, automobile repairing, security guard and Ansar as well as VDP. Each Hijra was provided with Tk 10,000 as financial aid for their replenishment. In 
the 2017-18 financial years, some 1,900 Hijra persons were provided training ("Number of Hijra stands at", 2018). Besides, different private television channels have already recruited five hijras to work for security. The steps which were taken by this private sector for providing employment opportunities are praiseworthy initiatives that will pave the way of going forward for this backward section. The Bangladesh Bank determined to impart loans to eligible hijras in notice since June 2015 all scheduled banks, the Bangladesh Bank instructed that they should take initiatives to encompass this disadvantaged group within their project for underpinning the tiny and moderate business. Besides, the Bangladesh Government decided to recruit them as traffic police ("Hijras to be recruited as traffic police", 2015). Various kinds of tutelage were provided to 350 hijras at the cost of $72,17,000 /-$ in total. In the financial year of 2013-2014, a monthly allowance of Tk. 300/- were granted to 1071 Hijras in 21 upazilas of 7 districts, 950 hijras were trained for 50 days, and 2010 hijras were given 10, 000/- to assist them to commence their enterprise. In the budgetary year of 2014-2015, their project has been expanded to 35 Zilla and setting the target to award monthly requital of 500/-, training to be provided to 50 hijras, and Tk.10, 000/- start-up money to 4020 hijras. He underscored gracefully that 18 hijras have been recruited among which 14 are working in MOSW (BSWS, 2015).

\section{Availability of basic health facilities}

In terms of access to health care, the Constitution of the People's Republic of Bangladesh states that it is the responsibility of the state to provide its citizen with medical care (Constitution, Article, 15). Hijras face more obstacles due to their womanly outlook collate to homophile whose erotic recognition is invisible in their manly effeminate sameness in terms of approachability to the health sector and other public job sectors (Bondyopadhyay \& Ahmed, 2010). The Hijras in Bangladesh are ill-treated in the health care services. Due to social exclusion, they face disparities in receiving basic health facilities in government hospitals. As most of them are involved in the commercial sex industry, they are more prone to be affected by sexually transmitted diseases and HIV. Also, they do not feel very comfortable going to the hospitals due to the socio-cultural perception of them (Chan \& Khan, 2007). Additionally, the health service providers have little understanding about the diverse sexual identities and are not very sensitive to behave properly with them (Joseph, 2013). Many Hijras are reluctant to go to Government hospitals. Hijras also express concern that when the general 
populace notices very much complexities in getting services, then what we will do and where will go, the doctors first look at our whole body albeit they have never kept in touch with us before and treat us as peculiar breeds come from a zoological garden and if we have to be admitted on discussion especially in which ward, however in some hospitals without any concern they admit us in woman wards. The panic of being admitted to the male wards put many Hijras away from Government hospitals (Chettiar, 2015).

\section{Political Status}

In Bangladesh, sometimes there is an experience of complete disregard of the people; sacred right to life due to lack of recognition. In Bangladesh, Hijras got recognition as transgender by the executive organ of the government ("Cabinet approves Hijras", 2013). The Constitution of the People's Republic of Bangladesh envisions that every citizen shall have the right to form a coalition or club subject to any logical restriction imposed by law for the sake of morals or public order (Constitution, Article, 38). So Hijras have the right to involve themselves in political activities, to ally themselves with any organization or alliance or political party which is the implication of this article. Besides, it has been enshrined in the constitution that every citizenry has the freedom of thought, speech, and conscience (Constitution, Article, 39). It is found that every citizen including Hijras has the right to express their thoughts can make demands along with other members of the society. The Hijra community is a sexual minority group, for this reason, they have been socially excluded from any other group in Bangladesh. They are also excluded politically. In the case of political equality, all people have entrance to the political affair and equal opportunity to go for any political post (Buergenthal, 1997). Every human personality, even the child in the womb has the inherent right to life endowed on to him (ICESCR, 1966, Article 25). The International Covenant on Civil and Political Rights states that every human being is entitled to enjoy their civil and political rights irrespective of sex, race, colour, sex, religion, or political or other opinions (ICCPR, 1966 Article 3). Bangladesh has officially recognized transgender as a separate gender or the third sex in 2013. Following the decision, Election Commission initiated a separate column on the voter registration form to identify them as transgender. Transgenders have the right of voting in the law. As they can cast their votes, they have also the right to run in elections in their respective area. Sadia Akter Pinki was elected vice-chairman of a Kotchandpur, from Jhenaidah after beating 
her nearest rival by more than 4,000 votes. Sadia Akter Pinki said that I am very pleased because I had gone door to door for campaigning and people have positively responded to me and I did not face any discriminatory attitudes during campaigning (bdnews24.com, 2019).

\section{Cultural Enjoyment}

As a matter of fact, during the early stage, most of them had to leave the families and started another chapter of their life which was their involvement with the Hijra community even though they loved to be with the families (Safa, 2016). Hence, they had to find out the Hijra guru within their community who would shelter them. In return, some of them were forced to be involved in the sex-trade; some of them did it willingly as they did not have any other thing to do for a living (Khan et al., 2008). Hijras are mistreated in Bangladesh. Many families are reluctant to accept the hijras as their family members. They often feel embarrassed to familiarize themselves with others and to bring them to the social program at their early ages on the ground that it may be worrisome for others (Islam, 2016). Another crucial phase of Hijra's life is their old age when they have to live alone being socially outcast. As they cannot do any kind of work at that time and do not have the connection with the family members, they have to fight illness and poverty every day (Islam, 2016). The Universal Declaration of Human Rights envisages that every human personality has the right to take part in the cultural life of society (UDHR, 1948, Article 26). But no Hijras are allowed to participate in the cultural life of the community except wedding ceremony, birthday party of children where they are being hired only for dance which is disgraceful because despite being a member of their families, they cannot enjoy the ceremonial program along with others family members (Khan et al., 2009). The United Nations Charter which envisions that to develop amicable bond amidst states based on estimation for the proposition of indistinguishable rights and self-reliance of the people as well as stimulate and motivate respect for human rights and fundamental freedom for all irrespective of race, sex (UNC, 1945, Article 26). The only unambiguous provision in the charter is the prohibition of discrimination (UNC, 1945, Article 26).

\section{Literature Review}

The ethnographic research has found that the childhood inclination of a biological male to 'female outfits', 'female manners' and domestic works is the key reason 
of inattention and disgrace in the family and the cases of sexual harassment by the close relatives (Khan et al., 2009) but has not been identified what other problems they face in leading their daily life, core reasons of the challenges and what will be the way forward. Besides, at this point, they also had to face difficulties in renting a house on their own, even if they had the affordability, as the landlords, in most of the cases, are not willing to provide the room on rent to them. As a sequel, they have to sleep in slums, parks, or streets where they have to face sexual persecution by the clients or by the aggressive and violent young criminals and even by the law enforcing agencies (Jebin \& Farhana, 2015). In this regard, the article has gaps to particularize how they are being deprived of their own family and what are the other challenges they face in their daily life despite prevalent laws and policies which deprive them of enjoying human rights. In 39 percent of the cases and those who left the school, for this reason, shared it with their parents or friends and complained to the school authority. Additionally, they want to get the benefits of the quota system in the case of admission to the school, college and university, and different job sectors. For this reason, they are targeting to be enlisted in different educational institutions. The right not to be differentiated against the relish of human and fundamental rights and is also degraded on the ground of status, whose states are expressively divergent fail to be served incongruously without open-minded justification. Persons who are hijras should be neither assiduous nor used as a populace that is unable to execute aims; for instance, liberty, self-support, and nobility except as human beings with idiosyncratic, inexhaustible flair. The primeval anti-stance underscores disability, regards enfeebled persons as the gadget of aid, and provides opportunities to the handicapped. This encompasses go wrong to furnish persons who are hijras, the constructive actions which are needed to have ingress to genuine services and opportunities ensuring initial, long-lasting, efficacious education, professional training, endowment, and health programs (Johanna, 2005). It has been found that those $(42 \%)$ who wanted to continue their studies had to leave the school due to harassment or parents' financial condition; even those (58 percent) who left the school of their own also faced the same difficulties, and $25 \%$ percent of them left school just because they did not like studying (Jebin, 2018). Hence the article has not focused on the effectiveness of the policy of 2013 where scholarship was provided on various levels or categories keeping in mind the overall development of the hijra community. In all spheres of life, hijras' rights to live and work as a human personality are infringed with immunity (Ghiselin, 1969). Hence, it is 
found that the author fails to particularize the social, educational, political, and cultural, and health facilities given the existing laws and policies over in terms of enjoyment of human rights and thus to find out the gaps of the existing laws and policies. In an article, Sarker and Pervin analysed the socio-economic status of the hijra community in Dhaka city where there are gaps to address the problems and challenges faced by the hijra community in line with the national laws, policies, and international mechanisms (Sarker and Pervin, 2020). Hijras are undernourished as communal anathema and differentiation made them unprocurable, horrifying, and hilarious (Jarne \& Auld 2006). Hence, the article has lacunas to identify the existing laws, policies for the development of the hijra community. They do not feel very comfortable going to the hospitals due to the socio- cultural perception about them as well (Chan \& Khan, 2007). In this regard, the writing did not find out the reason for socio-cultural perception and the way forward. Hijras also express concern that when ordinary people find so much difficulty in availing of services, then what about us and even when we do go, the doctors first look at us from top to bottom as though they have never heard nor seen us before and think we are a strange species come from a zoo and if we have to be admitted there is a discussion about in which ward we should be admitted, however in a few hospitals without any issue they admit us in female wards. The fear of being admitted to the male wards keeps many Hijras away from Government hospitals (Chettiar 2015). In this connection, the article has a gap to identify the reasons for being deprived of the health facilities in line with the existing laws and policies.

\section{Analysis of the Findings}

Hijras are treated inhumanely due to lack of recognition of society and implementation of existing laws and policies by the government and gaps of the prevalent laws and policies. The social and legal rights of the Hijras' analysis have been done keeping in mind their gender identity, what has been enshrined in the government, non-governmental organization steps, and private sectors. Hijra Dola said that they do not know the prevalent laws and policies in terms of enjoyment of their various rights very well. Hijra Dola expressed their sufferings to the researcher, "The Hijras, being excluded from the familial ties, they settle down themselves temporarily in different parts of the state". 
Table 2: Living behaviour of Hijra; researcher's dataset

\begin{tabular}{|l|c|c|}
\hline Living Behaviour & Frequency & Percentage (\%) \\
\hline With 'Guruma' & 23 & 76.7 \\
\hline Alone in rented house (in slums area) & 5 & 16.7 \\
\hline Parks and Streets & 2 & 6.6 \\
\hline \multicolumn{1}{|c|}{ Total } & $\mathbf{3 0}$ & $\mathbf{1 0 0}$ \\
\hline
\end{tabular}

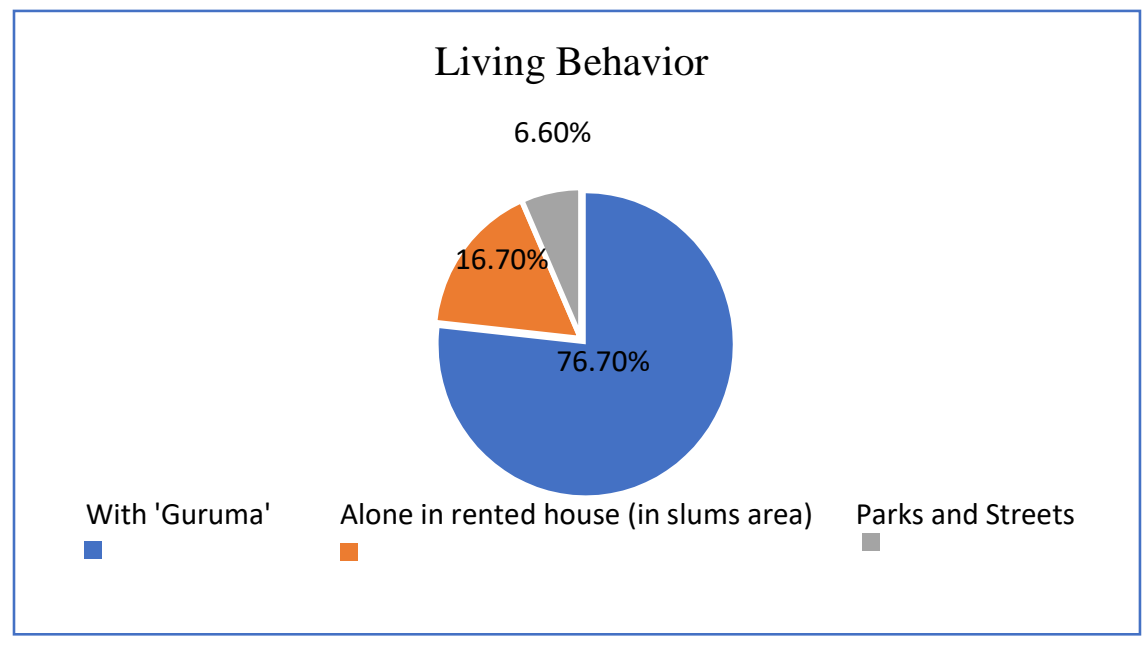

Figure 1: Living behaviour of Hijra.

Figure 1 illustrates that twenty-three (76.70\%) of the participants having been excluded from their familial ties, have been living collectively with their guru whereas five $(16.7 \%)$ hijras have been passing their days in the rented house particularly in slum areas alone and two (6.6\%) of them have been breathing in the parks and streets collectively or individually.

Hence, it goes without saying that no justice can be ensured leaving behind one community like Hijras. Hijra has inherent right to stay together, to grow up within the familial structure; no one can deprive them to exercise their right which is not only discriminatory but also a violation of the provisions of the constitution of the People's Republic of Bangladesh, Universal Declaration of Human Rights 1948. Hijra Nodi, living in Chankharpool, expressed that: 
In school, they cannot share anything necessary for their development or for nourishing themselves with the classmates who have been inflated from classroom to playground.

Tanzila Hijra claimed that:

Hijras are not getting the facilities of being educated because they have stayed away from their families which lead them to begin in the street and thus, they are not getting the chance of admission to any school in Bangladesh to remove this picture from the society. Hijra are trying their best to get educated from academic institutions but they are facing various difficulties from teachers, students and others.

Table 3: Education Facilities enjoyed by Hijra; Author's dataset

\begin{tabular}{|c|c|c|}
\hline Education Facilities & Frequency & Percentage (\%) \\
\hline Discriminatory & 21 & 70 \\
\hline Facilitated & 7 & 23.30 \\
\hline Non-facilitated & 2 & 6.70 \\
\hline Total & $\mathbf{3 0}$ & $\mathbf{1 0 0}$ \\
\hline
\end{tabular}

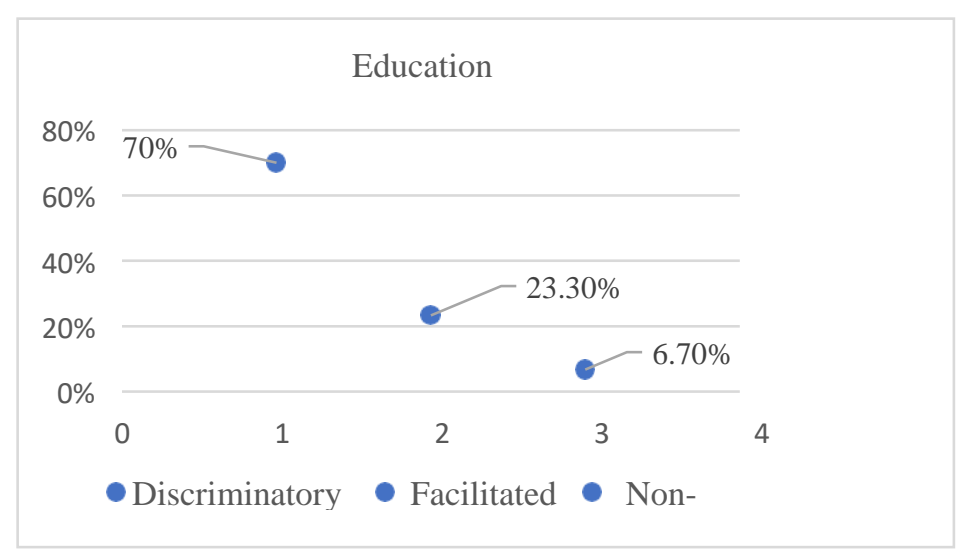

Figure 2: Education Facilities enjoyed by Hijra.

Table 3 and Fig. 2 show that $70 \%$ of the respondents face discriminatory attitude in terms of enjoyment of the educational facilities such as enrolment in school, using the library, sanitary, etc. in school whereas $23.30 \%$ of participants can enjoy the opportunity of various institutional facilities and $6.70 \%$ participants did not get any kind of facilities while going to school. 
Table 4: Problems of schooling faced by Hijra; Researcher's dataset

\begin{tabular}{|l|c|c|}
\hline \multicolumn{1}{|c|}{ Problems of Schooling } & Frequency & Percentage (\%) \\
\hline Bullying/scolding in classroom & 13 & 43.30 \\
\hline $\begin{array}{l}\text { Bullying/scolding in } \\
\text { Playground }\end{array}$ & 15 & 50 \\
\hline Teacher's discriminatory attitude & 2 & 6.70 \\
\hline \multicolumn{1}{|c|}{ Total } & $\mathbf{3 0}$ & $\mathbf{1 0 0}$ \\
\hline
\end{tabular}

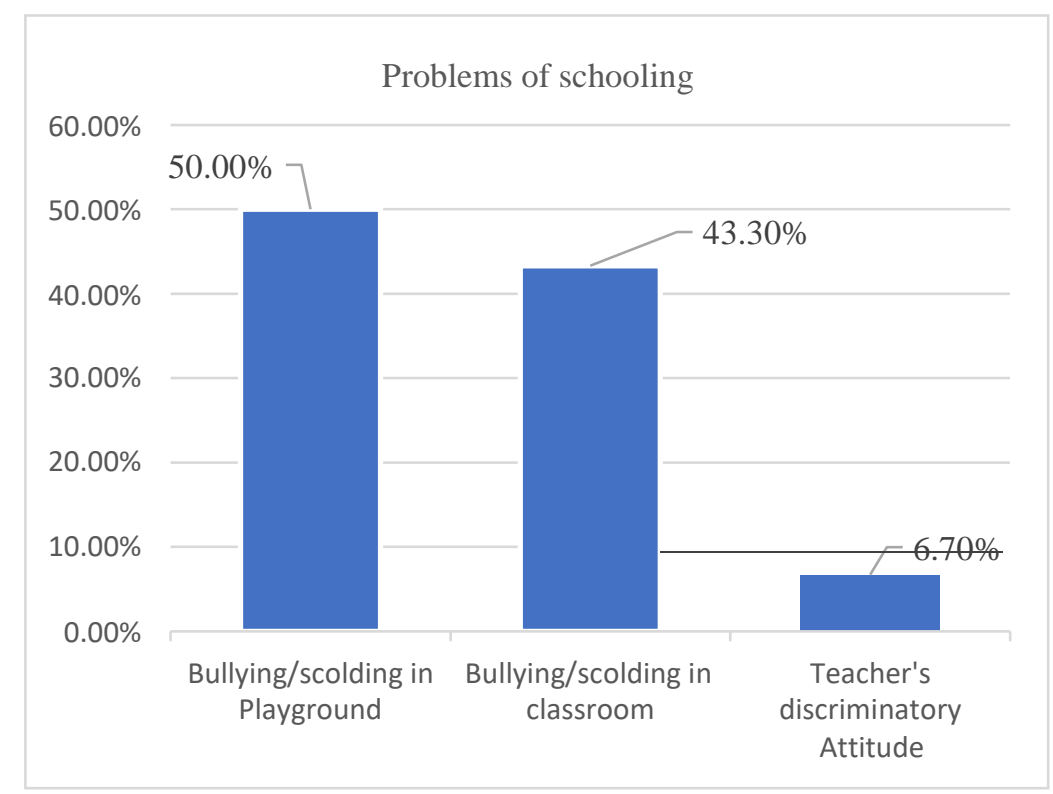

Figure 3: Problems of schooling faced by Hijra.

Thirteen $(43.30 \%)$ of the participants face bullying/scolding while sitting in the classroom which makes them embarrassed to sit together with other students and that leads them not to behave cordially with their classmates. Consequently, hijras feel discouraged to attend school regularly. Similarly, fifteen (50\%) hijras cannot play in schools' playground with their classmates due to scolding /bullying which makes the hijras to do aggressive attitude whereas two $(6.70 \%)$ hijras face discriminatory attitude from the teacher whenever they make complain to the teacher regarding the problem what they face in the classroom and playground (Fig. 3). 
Hijra community must be given a convenient environment in school and thus step by step will be highly educated like other members in the mainstream society. The unusual growth of Hijras is not tolerated in school where they often encounter hostile environments for incompatible sex gender. As Hijra Rani said that:

As they are the offspring of their parents, they cannot be lagged, abhorred, and devalued by their parents. For this reason, they are fighting for equal treatment in the same way as other members; otherwise, they will remain neglected in the society which shall expedite their backwardness in all spheres of life. Hence, family can do or change everything necessary for their developments because family is the first institution for the proper nourishment of the children in this world. For the social inclusion of Hijras as a member of society, continuing schooling is mandatory to create a gender-friendly environment. To this end, introducing quota system is a must for the overall development of hijra community.

Bristi regrets to the researcher:

Though they have little access in a government hospital but are not diagnosed properly by the doctors. Besides, they are being considered by the doctors in a private hospital as a burden, if any Hijra suffers from any disease, they go to the government hospitals where they receive disparaging behaviours from both staffs and the doctors.

Table 5: Health facilities received by Hijra; Researcher's dataset

\begin{tabular}{|c|c|c|}
\hline Treatment & Frequency & Percentage (\%) \\
\hline $\begin{array}{l}\text { Hijras are not diagnosed in } \\
\text { government hospitals }\end{array}$ & 13 & 43.30 \\
\hline $\begin{array}{l}\text { Hijras are considered } \\
\text { a burden by doctors in private } \\
\text { hospital }\end{array}$ & 9 & 30 \\
\hline $\begin{array}{|lrr|}\text { Hijras face } & \text { disparaging } \\
\text { behaviour } & \text { in } & \text { the } \\
\text { government's } & & \text { hospitals, } \\
\text { healthcare } & \text { centres, } & \text { and } \\
\text { dispensaries } & & \end{array}$ & 8 & 26.70 \\
\hline Total & 30 & 100 \\
\hline
\end{tabular}




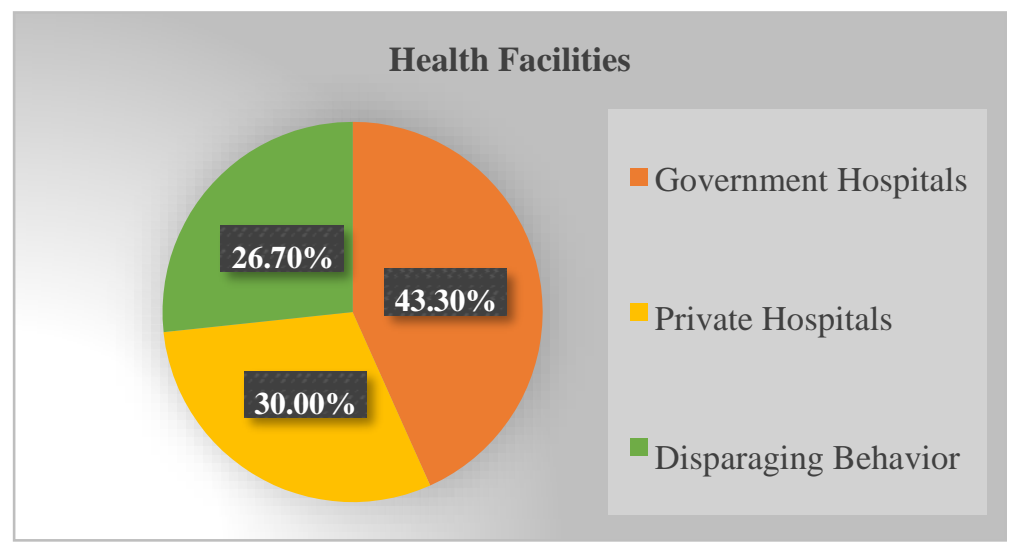

Figure 4: Health facilities received by Hijra.

Figure 4 illustrates that $46.70 \%$ of respondents are not diagnosed in the government hospital for their treatment whereas $20 \%$ get disparaging behaviour in government hospitals, healthcare centres, and dispensaries. At the same time, $33.3 \%$ is considered a burden by doctors in private hospitals.

For the inclusion of Hijras in the mainstream society to get proper treatment, every person in health sectors should be intimated of making them as a social friendly member as well as to extend all kinds of health facilities to them. Anarkali and Tanzila complained, "They are not getting any kind of work to survive themselves, even though they get a job in some sectors but they are being terminated after knowing their sexual identity". Hijra Mukti claimed, "They are not getting jobs due to lack of education, peculiar lifestyle; they are considered as unfit for the working environment which leads them to survive as a sex worker".

It is a well-established notion that every work is dignified and shall be paid according to his/her ability and work. But realities are not the same as provided in the legal arena. They have no social, religious, and legal, and constitutional human rights. Ensuring equal opportunity with due respects to others' rights as a particular human personality; can contribute towards the development of society. In this connection, a peaceful gender-friendly environment can lead to promoting human dignity where no difference can be made to lower the status of the Hijra community. Immaculate courtesy and impeccable manners as well as vocational education will be helpful to make them adaptive behaviour and thus they could be employed in various job sectors. Hijra Pori said, "They are being fired in job 
sectors on the ground of demolishing the job environment which will not ensure equality, justice in the society".

Table 6: Livelihoods of Hijra; Researcher's dataset

\begin{tabular}{|c|c|c|}
\hline Income Sources & Frequency & Percentage $(\%)$ \\
\hline Begging and Chanda Tola & 25 & 83.3 \\
\hline Jobs (private sectors) & 3 & 10 \\
\hline Parents & 2 & 6.7 \\
\hline Total & 30 & 100 \\
\hline
\end{tabular}

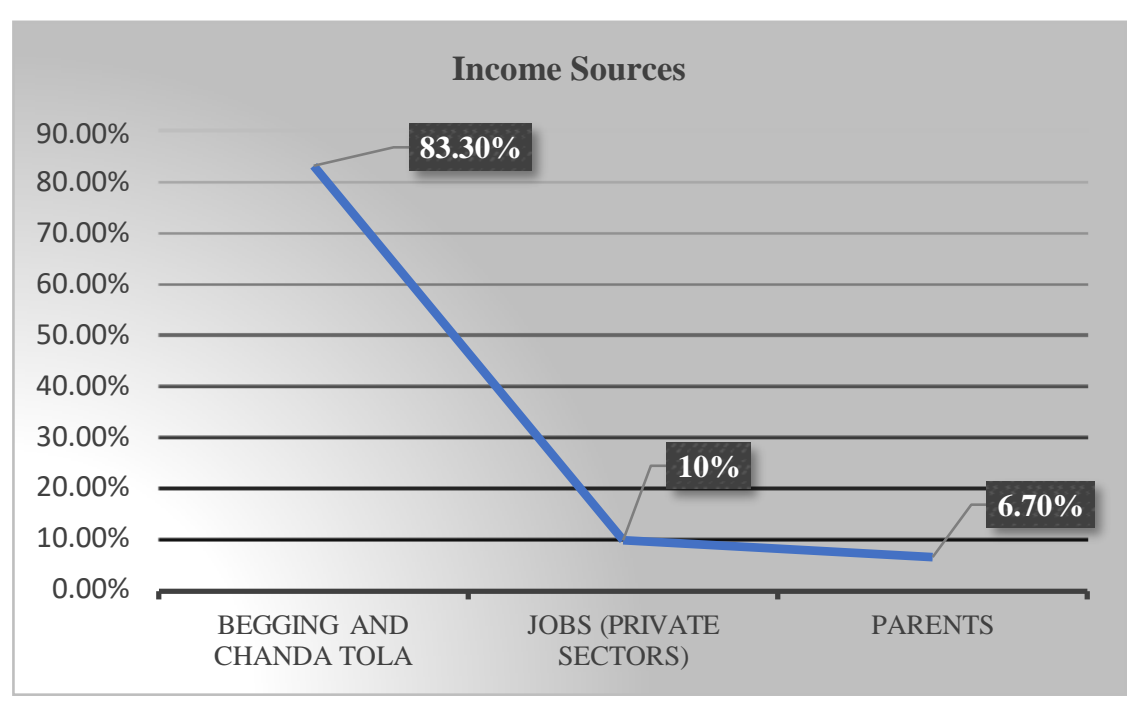

Figure 5: Livelihoods of Hijra.

Twenty-five (83.30\%) participants earn their livelihoods by begging and chanda in streets, bus, and trains as well as from residential areas by blessing the newborn child or dancing in various social programs when invited to perform to dance whereas three (10\%) hijras are recruited in private sectors as the security guard or cleaner and only two $(6.70 \%)$ of them receive money from their parents by living separately (Fig. 5). Hence, it can be said that despite having the strength of working in various sectors according to the nature of the jobs, they are abhorred by society due to lack of education. The government of Bangladesh has 
recognized the hijras by terming them as "transgender" in Bangladesh's national voter list (Wallen, 2019). Hijra Rakhi expressed that view, "They have no political rights by which they can represent in the affairs of the state".

Hence, Hijras' rights as a human being cannot be violated, isolated, and neglected, as well as cannot be politically abandoned as a part of the society. Hijra Moni stated:

In Bangladesh, they are fighting for getting different kinds of opportunities as provided by the state through the voices (by arranging seminars, workshops) and writings of civil society as well as by media. They think that members of civil society may be able to convince the general people in the society regarding their existence, rights and thus will be honoured as well as love will be embedded in the hearts of human personalities which will help them to take part in different activities for their up-gradation.

Table 7: Voting Rights of Hijra; Author's dataset

\begin{tabular}{|l|c|c|}
\hline Voting Rights of Hijra & Frequency & Percentage (\%) \\
\hline Can cast vote & 18 & 60 \\
\hline Cannot cast vote & 11 & 36.70 \\
\hline Representatives & 1 & 3.30 \\
\hline \multicolumn{1}{|c|}{ Total } & $\mathbf{3 0}$ & $\mathbf{1 0 0}$ \\
\hline
\end{tabular}

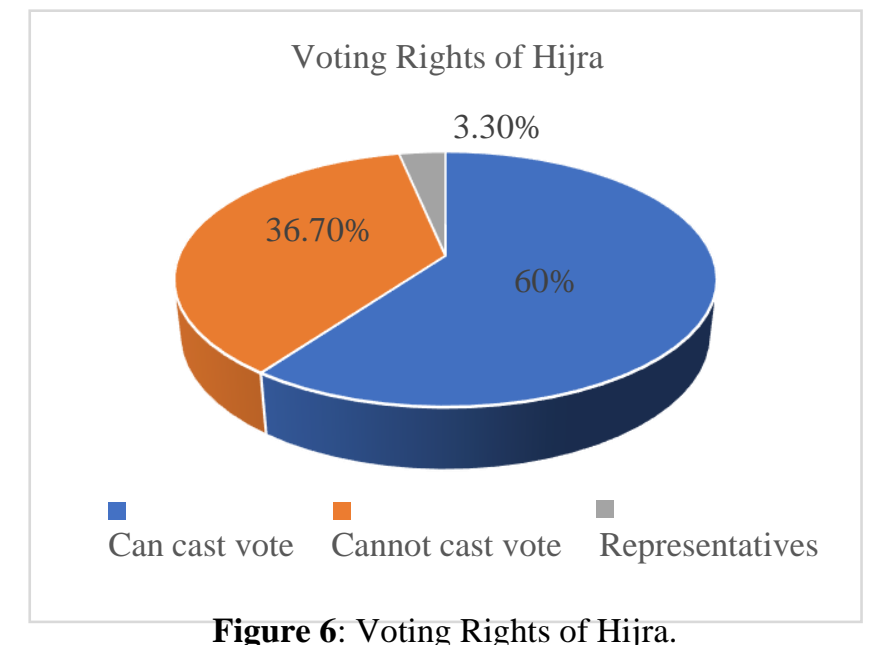

Figure 6: Voting Rights of Hijra. 
Eighteen (60\%) of the respondents think that they can enjoy the right to cast their vote whereas eleven participants $(36.70 \%)$ opine that they cannot exercise their voting right due to several reasons such as lack of availability of national identity card, not having social acceptance, etc. Additionally, only one (3.30\%) participant argues that they can take the chance of being representatives in the same way as other citizenries (fig. 6).

\section{Future Challenges}

Firstly, changing the values and norms of the society will be the most challenging actions to recognize the hijras in mainstream society and to persuade each family to ensure the human rights of the hijra community.

Secondly, to convince every family and teachers, school friends to create an amicable ambiance to help the hijra community to enjoy all facilities as a human being which are provided and guaranteed by national and international mechanisms (which other students and other school friends enjoy as a student) as well as which are pre-requisite for their survival.

Thirdly, enabling the hijra community to raise their voice to enjoy human rights from family, teachers and friends, hospitals and doctors as well as other staffs will be a clear sign in furtherance of the social status of hijras.

Fourthly, establishing separate institutions for their educational facilities is a big challenge while the society has been facing other challenges like poverty, natural calamities, etc.

Finally, to make effectiveness and application of prevalent laws and policies by framing rules or guidelines and thus fill up the gaps of the existing laws and policies to address the problems and challenges faced by them in collaboration with the relevant ministries like social welfare ministry, law ministry, ministry of education, labour ministry, etc.

\section{Recommendations}

Following recommendations can be prioritized to sort out the existing and future challenges for the Hijra community to embrace them in the mainstream society:

a) To make the hijras socially friendly members, all sectors especially civil society can help to a great extent by changing the societal attitudes towards this section. 
b) Government and NGOs should adopt various social awareness programs such as, hanging up the billboard on the road site by putting down that Hijras are also like all other members of the family and society which will persuade their family and society to cordially accept them.

c) Teachers and school friends have to be understood that they have the duties and obligation to provide and support all kinds of educational facilities to make the hijras qualified, to ensure human rights, and to grow up as an educated citizenry.

d) Mass media of the country like the Bangladesh Betar, various television channels can play a vital role by advertising the importance of providing educational facilities in making them enlighten people.

e) The Hijra community may be received the benefits of the quota system in the case of getting admission to all educational institutions as well as in different job sectors.

f) Volunteer organizations may be formed comprising the local young doctors or nurses to help the hijras to enjoy the equal health facilities provided by the hospitals.

g) As separate institutions for other backward sections have already been established like autistic or physically disabled children. Hence, it is possible to set up a distinct institution for Hijra community to make them the efficient member of the society by providing educational facilities which are enshrined in the existing laws and policies.

\section{Conclusion}

Upon considering the historical, theoretical, and practical aspects of the given existing laws and policies, it is manifested that the status of Hijras is not the same as enshrined at various national and international mechanisms, due to the gaps and lack of effectiveness as well as application of the existing laws, policies, and lack of cordial behaviour, and neglectful attitude of the family as well as lack of knowledge of hijras about the prevalent laws, policies. Therefore, it is high time to accept them as full-fledged members of the society considering the international and national laws, policies as well as to fill up the gaps of the existing laws and policies. Now, the time has come to consider the human rights of this community and to reduce the menace and thus to protect the Hijra 
community from these adversities of discrimination by application and implementation of the prevalent time befitting laws and policies as well as by enacting the rules and guidelines following the prevalent law and policies to ensure the human rights of this community. It is always to be remembered that the enactment of laws and policies do not stop the sufferings of the hijra community or ensure human rights. Towards this end, hijras must be made aware about the human rights and all members of society should help the government to implement and apply the existing laws to ensure their acceptability in the mainstream society. To do that, social norms, education, and behavioural pattern of social relations may be reshuffled.

\section{References}

Bandhu Social Welfare Society (BSWS) (2015). Third gender is not a word, it is a Gender. This paper was presented in a seminar organized by Bandhu Social Welfare Society and National Human Rights Commission on $29^{\text {th }}$ April 2015. Retrieved from https://www.bandhubd.org/third-gender-is-not-a-word-it-is-a- gender/ (Accessed on November 25, 2019).

Bdnews24.com (2019, October 15). Transgender woman becomes vice chairman in Jhenaidah. Retrieved from https://bdnews24.com/people/2019/10/15/transgender-woman-becomes-vicechairman-in-jhenaidah, (Accessed on February 26, 2021).

Bondyopadhyay, A., \& Ahmed, S. (Eds.) (2010). Same-Sex Love in a difficult climate: A study into the Life Situation of Sexual Minority (Lesbian, Gay, Bisexual, Kothi and Transgender) Persons in Bangladesh. Dhaka: Bandhu Social Welfare Society.

Buergenthal, T. (1997). The normative and institutional evolution of International Human Rights. Journal of Human Rights Quarterly, 19(4), 707. Retrieved from https://www.jstor.org/ stable/pdf/762684.pdf?seq=1 (Accessed on November 10, 2019).

Cabinet approves Hijras Identity. (2013, November 11). The Daily Star. Retrieved from https://www.thedailystar.net/news/cabinet-approves-hijra-identity (Accessed on July 7, 2019).

Chakrapani, V. (2010). Transgender women in India: HIV, Human Rights and Social Inclusion. UNDP, India. Retrieved from http://www.undp.org/content/dam/india/docs/ hijras_transgender_in_india_hiv_human_rights_and_social_exclusion.pdf (Accessed on October 28, 2019).

Chan, A. P., \& Khan, A. O. (2007). Risk factors for HIV infection in males who have sex with males (MSM) in Bangladesh, BMC Public Health, 7(1), 153. doi: 10.1186/1471-2458-7-153

Chettiar, A. (2015). Problems Faced by Hijras (Male to Female Transgender) in Mumbai with Reference to Their Health and Harassment by the Police, International Journal of Social Science and Humanity, 5(9), 752-759.

Chowdhury, S. (2020, November 6). Transgender in Bangladesh: First School Opens for trans students, BBC Bangla Retrieved from https://www.bbc.com/news/world-asia- 54838305, (Accessed on February 27, 2021).

Ghiselin, T. M. (1969). The evolution of hermaphroditism among animals. The Quarterly Review of Biology, 44(2), 189-208. 
Gubrium, F. J., \& Holstein, A. J. (Eds.) (2001). Handbook of Interview Research: Context and Method (pp. 30-58). USA: California, Thousand Oaks: Sage Publications.

Gul, M. (2018). History of Marginalized Community. Retrieved from https://www.dandc.eu/en/ article/british-introduced-discrimination-transgender-persons-south-Asia, (Accessed on July $28,2019)$

Hahm, C. S. (2010). Striving to survive: Human security of Hijra in Pakistan. Conflict, Reconstruction and Human Security (CRS), 26. Retrieved from http://hdl.handle.net/ 2105/8652 (Accessed on June 11, 2019).

Hijras to be recruited as traffic police. (2015, May 19). Dhaka Tribune. Retrieved from https://www.dhakatribune.com/uncategorized/2015/05/19/hijras-to-be-recruited-as-trafficpolice (Accessed on July 5, 2019).

Hossain, A. (2012). Beyond Emasculation: Being Muslim and Becoming Hijra in South Asia. Asian Studies Review, 36(4), 495-513.

International Covenant on Economic, Social, Cultural Rights (ICESCR). (1966). A resolution adopted by General Assembly of UN on 16 December 1966. Retrieved from https://www.ohchr.org/en/professionalinterest/pages/cescr.aspx, (Accessed on October 14, 2019).

International Covenant on Civil and Political Rights (ICCPR). (1966). A resolution adopted by General Assembly of UN on 19 December 1966. Retrieved from https://treaties.un.org/doc/ publication/unts/volume\%20999/volume-999-i-14668-english.pdf, (Accessed on October 14, 2019).

Islam, A. (2016). Right to education of the third gender of Bangladesh: An Overview. IOSR Journal of Humanities and Social Science, 21(9).

Jarne, P., \& Auld, J. R. (2006). Animals mix it up too: the distribution of self-fertilization among hermaphroditic animals. Evolution, 60(9), 1816-24.

Jebin, L., \& Farhana, U. (2015). The Hijras Human Rights in Bangladesh: An Overview. Journal of Nazrul University, 3(1\&2).

Jebin, L. (2018). Status of transgender people in Bangladesh: a socio- economic analysis, South Asian Journal of Policy and Governance, 42(1), 49-63.

Joseph, D. (2013). Social exclusion of transgender: Problems and prospects. Indian Social Science Journal, 2(1), 73. Retrieved from https://www.questia.com/library/journal/1P33169641251/social-exclusion-of-transgender-problems-and-prospects, (Accessed on November 12, 2019).

Khan, S. I., Hussain, M. I., Gourab, G., Parveen, S., Bhuiyan, M. I., \& Sikder, J. (2008). Not to stigmatize but to humanize sexual lives of the transgender (Hijra) in Bangladesh: Condom chat in the AIDS era. Journal of LGBT Health Research, 4 (2-3), 127-141.

Khan, S. I., Hussain, M. I., Parveen, S., Bhuiyan, M. I., Gourab, G., Sarker, G. F., Arafat, S. M. \& Sikder, J. (2009). Living on the Extreme Margin: Social Exclusion of the Transgender population (Hijra) in Bangladesh. Journal of Health Population and Nutrition, 27(4), 441-451.

Maritain, J. (2012). Christianity and Democracy, the Rights of Man and Natural Law. USA: Ignatius Press.

Mayo, B. (1967). What are Human Rights? In D. D. Raphael (Ed.), Political Theory and the Right of Man (p. 68). USA: The University of Michigan, Indiana University Press.

Mckeown, T. (1988). The origin of human disease. England: Blackwell Publishers. 
Miller, C. M. (2004). Athens and Persia in the Fifth Century BC: A Study in Cultural Receptivity (p. 213). Cambridge: Cambridge University Press.

Nanda, S. (1999). Neither man nor woman: The Hijra of India (p. 22). New York: Albany, Wadsworth Publishing Company.

Number of Hijra stands at 11,039. (2018, June 24). The New Age. Retrieved from https://www.newagebd.net/article/44330/number-of-hijra-stands-at-11039-says-minister (Accessed on November 15, 2019).

Oksala, J. (2005). Foucault on Freedom. Cambridge: Cambridge University Press.

Pagels, E. (1979). The Roots and Origin of Human Rights. In Alice H. Henkin (Ed.), Human Dignity: The Internationalization of Human Rights (p. 2). New York: Oceana.

Reddy, G. (2005). With Respect to Sex: Negotiating Hijra Identity in South India. Chicago: University of Chicago Press.

Safa, N. (2016). Inclusion of excluded: Integrating need Based concerns of Hijra population in mainstream development. Sociology and Anthropology, 4(6), $450-458$

Sarker, A. A. (2007). Right to equality under the constitution of Bangladesh in Human Rights and Corruption. In Mizanur Rahman (Ed.), Human Rights and Corruption (p. 217). Dhaka: ELCOP.

Sarker, K. B., \& Pervin, T. (2020). Socio-economic Status of Hijra Community: A Study on Dhaka City. International Journal of Science and Business, 4(1), 276-284.

Stenqvist, T. (2015). The social struggle of being HIJRA in Bangladesh: cultural aspiration between inclusion and illegitimacy (Masters thesis, Malmö University, Sweden). Retrieved from https://muep.mau.se/bitstream/handle/2043/18568/Stenqvist-T-DP15\%20final.pdf (Accessed on January 17, 2020).

The Constitution of the People's Republic of Bangladesh 1972. Retrieved from http://bdlaws.minlaw.gov.bd/act-367.html (Accessed on November 12, 2019).

United Nations Development Programme (UNDP) \& Asia Pacific Transgender Network (APTN) (2017). Legal Gender Recognition: A Multi-Country Legal and Policy Review in Asia, UNDP and Asia Pacific Transgender Network. Retrieved from https://www.undp.org/content/dam/rbap/ docs/Research\%20\&\%20Publications/hiv_aids/rbaphhd-2017-legal-gender-recognition.pdf (Accessed on January 17, 2020).

United Nations (UN). (1945). The United Nations Charter (UNC) 1945, Article 26. Retrieved from https://www.un.org/en/sections/un-charter/un-charter-full-text/ (Accessed on November 18, 2019).

Universal Declaration of Human Rights (UDHR). (1948). Universal Declaration of Human Rights. Retrieved from https://www.ohchr.org/EN/UDHR/Documents/UDHR_Translations/eng.pdf (Accessed on July 5, 2019).

West, C., \& Zimmerman, H. D. (1987). Doing Gender. Gender and Society, 1(2), 125-151.

Wallen, J. (2019, April 29). Transgender community in Bangladesh finally granted full voting right. The Telegraph. Retrieved from https://www.telegraph.co.uk/global-health/climate-andpeople/transgender-community-bangladesh-finally-granted-full-voting/ (Accessed on November 7, 2019). 